\title{
Genetic divergence of sugarcane varieties collected in the region of Lavras, Minas Gerais, Brazil
}

\author{
L.E.V. Cesar, A.T. Bruzi, J.A.R. Nunes, L.A. de B. Andrade, M.F. Lopes, \\ L.R. Sales and M.M. Mourão \\ Departamento de Agricultura, Universidade Federal de Lavras, Lavras, MG, Brasil \\ Corresponding author: L.E.V. Cesar \\ E-mail: levcesar@uol.com.br \\ Genet. Mol. Res. 14 (4): 14043-14049 (2015) \\ Received April 10, 2015 \\ Accepted July 31, 2015 \\ Published October 29, 2015 \\ DOI http://dx.doi.org/10.4238/2015.October.29.23
}

ABSTRACT. Genetic diversity among local accessions and varieties subsidize plant breeding programs, allowing the utilization of existing variability in plants that have already adapted to local climate conditions. An alternative to studying genetic variability is the study of diversity. The aim of this research was to study genetic diversity among sugarcane accessions and varieties used for the production of craft-distilled cachaça (distilled sugarcane alcohol) in the region of Lavras, Minas Gerais, Brazil. Using a one-way design, an experiment was conducted in the municipality of Perdões, Minas Gerais to evaluate 35 regional accessions derived from germplasm collection expeditions and four varieties. Using morphological descriptions of 46 multicategorical sugarcane characteristics, dissimilarity and Tocher cluster method analyses were performed. Based on the results, it was concluded that genetic diversity exists among the accessions evaluated for the target traits.

Key words: Saccharum spp; Characterization; Dissimilarity; Cluster analysis 


\section{INTRODUCTION}

Studies of genetic diversity provide information about traits used to identify parents, and they facilitate the discovery of duplicates in germplasm banks (Rodrigues et al., 2002). Estimates of genetic diversity among local accessions and cultivars subsidize plant breeding programs, allowing the utilization of existing variability in plants that have already adapted to local climatic conditions. The morphological and agronomic characterizations of plants grown are of the utmost importance when determining the genetic divergence of available germplasm sets (Franco et al., 2001).

In this context, genetic diversity inferences can be made in both quantitative and predictive manners. Quantitative methods are diallel analyses that include crosses between the parents, followed by subsequent evaluation. The predictive methods have morphological differences and are based on nutritional, physiological, or molecular quality, which is quantified as the measurement of dissimilarity expressing the degree of genetic diversity between parents (Cruz and Carneiro, 2006). According to the same author, dissimilarity studies serve the various aims of breeders because they provide information on the degree of similarity or the difference between two or more genotypes, and they may be used as a tool for genetic divergence studies. However, the resulting number of dissimilarity estimates is relatively high when there is a large number of genotypes, and hence recognition of homogeneous groups by a simple visual examination is sometimes unfeasible. Therefore, the use of methods that cluster genotypes may be one of the best alternatives for data analysis and interpretation.

There are various clustering methods that differ by the type of result provided and by the different manners used to define the proximity between an individual and an already formed cluster (or between any two clusters). Among these, the optimization clustering method, or Tocher method (Cruz and Carneiro, 2006), constitutes a simultaneous clustering method, which separates genotypes into clusters in a single operation. This method uses a single clustering criterion, and it specifically presents a mean distance within clusters that is always less than the mean distance between clusters.

The Tocher method has been widely used in the study of genetic divergence among accessions. Souza et al. (2005) evaluated the genetic divergence among 31 watermelon genotypes using clustering techniques and canonical variables. In the study of Oliveira et al. (2004), the Tocher method was also used to evaluate genetic divergence among lettuce genotypes. Marchioro et al. (2003) used the Tocher clustering method for the evaluation of genetic dissimilarity among oat genotypes, and Silva et al. (2005) used the method to evaluate genetic diversity among sugarcane varieties. Moreover, Karasawa et al. (2005), when working with tomato crops, used the Tocher method to evaluate the genetic divergence among germplasm bank accessions, which facilitated the identification of potential parents for use in breeding programs.

Therefore, the aim of the present study was to examine genetic divergence among sugarcane accessions in the region of the municipality of Lavras, Minas Gerais, Brazil.

\section{MATERIAL AND METHODS}

The experiment was conducted in the commercial sugarcane production area of the Cachaça Artesanal João Mendes company (craft-distilled sugarcane alcohol company), located at the farm site Vó Zirica (highway BR-381, km 666) in the municipality of Perdões, Minas Gerais, Brazil, at 842 meters altitude, $21^{\circ} 05^{\prime} \mathrm{S}$ and $45^{\circ} 05^{\prime} \mathrm{W}$. According to the Köppen classification, the 
climate in Perdões is Cwb, which is characterized by a dry season from April to September and a rainy season from October to March. The region has a mean annual rainfall of $1493.2 \mathrm{~mm}$ and a mean temperature of $19.3^{\circ} \mathrm{C}$ (Dantas et al., 2007).

In this trial, 35 accessions were evaluated, and these were derived from a germplasm collection from rural properties with craft-distilled cachaça production in municipalities located in the region of Lavras, Minas Gerais (Coqueiral, Itutinga, Lavras, Nepomuceno, Perdões, and Ribeirão Vermelho) (Table 1). The germplasm collection was undertaken from November to December 2011 from four cultivars (RB867515, SP80-1842, SP79-1011, and SP81-3250) (Table 1).

Table 1. List of varieties and accessions examined in the experiment.

\begin{tabular}{|c|c|c|c|c|c|}
\hline Collection & Local & Description & Collection & Local & Description \\
\hline Accession 1 & Lavras & L1 & Accession 21 & Lavras & L21 \\
\hline Accession 2 & Lavras & L2 & Accession 22 & Nepomuceno & N22 \\
\hline Accession 3 & Lavras & L3 & Accession 23 & Nepomuceno & N23 \\
\hline Accession 4 & Perdões & P4 & Accession 24 & Rib. Vermelho & RV24 \\
\hline Accession 5 & Perdões & P5 & Accession 25 & Rib. Vermelho & RV25 \\
\hline Accession 6 & Perdões & P6 & Accession 26 & Rib. Vermelho & RV26 \\
\hline Accession 7 & Lavras & L7 & Accession 27 & Lavras & L27 \\
\hline Accession 8 & Lavras & L8 & Accession 28 & Nepomuceno & N28 \\
\hline Accession 9 & Lavras & L9 & Accession 29 & Lavras & L29 \\
\hline Accession 10 & Lavras & L10 & Accession 30 & Lavras & L30 \\
\hline Accession 11 & Perdões & P11 & Accession 31 & Coqueiral & C31 \\
\hline Accession 12 & Lavras & L12 & Accession 32 & Itutinga & 132 \\
\hline Accession 13 & Perdões & P13 & Accession 33 & Lavras & L33 \\
\hline Accession 14 & Perdões & P14 & Accession 34 & Perdões & P34 \\
\hline Accession 15 & Lavras & L15 & Accession 35 & Perdões & P35 \\
\hline Accession 16 & Perdões & P16 & RB867515 & RIDESA & V36 \\
\hline Accession 17 & Perdões & P17 & SP80-1842 & Copersucar & V37 \\
\hline Accession 18 & Perdões & P18 & SP79-1011 & Copersucar & V38 \\
\hline Accession 19 & Lavras & L19 & SP81-3250 & Copersucar & V39 \\
\hline Accession 20 & Lavras & L20 & - & - & - \\
\hline
\end{tabular}

Experimental planting was conducted from December 5 to 12, 2011, and the trial was set up as a one-way type design with 39 genetic treatments. Plots consisted of three $3.0 \mathrm{~m}$ rows with $1.3 \mathrm{~m}$ spacing between rows. The experimental area chosen had a recent history of use as a pasture and for corn cultivation. Soil acidity had been amended, and the soil was well managed and conserved, with complete contour lines and the absence of erosion.

Prior to experimental planting, the soil was prepared through plowing and two diskings. Furrows were then opened at $30-40 \mathrm{~cm}$ depths and spaced at $1.3 \mathrm{~m}$. For planting, a manual system was adopted where the cultivars and accessions were distributed within the plots according to a drawing designed prior to the experiment. The sugarcane billets were cut with three buds and distributed within the rows, and six billets were placed per linear meter for a total of $18 \mathrm{buds} / \mathrm{m}$. The billets were manually covered using hoes, and a layer of approximately $10 \mathrm{~cm}$ soil was placed over the billets distributed in the planting rows.

Fertilization at planting was performed with $40 \mathrm{~kg} / \mathrm{ha} \mathrm{N}, 140 \mathrm{~kg} / \mathrm{ha} \mathrm{P}_{2} \mathrm{O}_{5}$, and $100 \mathrm{~kg} /$ ha $\mathrm{K}_{2} \mathrm{O}$. In February 2012, sidedressed fertilization was conducted with the application of $60 \mathrm{~kg} /$ ha $\mathrm{N}$. For weed control, a chemical method was adopted using herbicides at the pre-emergence of the crops and weeds via $2 \mathrm{~kg}$ of a commercial product composed of $468 \mathrm{~g} / \mathrm{kg}$ diuron $+132 \mathrm{~g} /$ $\mathrm{kg}$ hexazinone, which is a selective herbicide for sugarcane crops that is derived from a group of substituted triazinones and ureas. 
Approximately twelve months after planting, the morphological characterization of each experimental plot was performed with the aid of the document "Descritores Botânicos da Canade-Açúcar" ("Botanical Descriptive Features of Sugarcane") published in the Diário Oficial da União (Official Government Registry) from march five thousand nine hundred ninety-eight (n 43-Seção I, pages 95 to 98). This document contains the description of 46 morphological variables that differentiate the botanical structure of sugarcane accessions and varieties for the purpose of individualizing each genotype. This allows the use of this information in studies of genetic divergence where accessions and cultivars are clustered in different blocks, and it aids breeders in choosing parents with greater potential for use in sugarcane breeding programs.

The morpho-agronomic traits were used as multicategorical variables, thus estimating dissimilarity by means of a similarity index $\left(\mathrm{S}_{\mathrm{iij}}\right)$.

$$
S_{i \ddot{\prime}}=C / C+D
$$

where: C: agreement of the category; D: disagreement of the category.

With this index, it is possible to express the percentage of similarity coincidence considering the various traits analyzed. Thus an $S_{i i}$ value equal to 0.50 reveals that the two genotypes ( $i$ and $i^{\prime}$ ) are similar in $50 \%$ of the multicategorical characteristics studied.

Dissimilarity $\left(\mathrm{d}_{\mathrm{ii}}\right)$ is given by:

$$
d_{i i^{\prime}}=C / C+D
$$

where: C: agreement of the category; D: disagreement of the category.

Cluster analyses were conducted using these estimates, and the Tocher optimization methods were adopted. In this analysis, it is necessary to obtain a matrix of dissimilarity where the most similar pair of accessions is identified. These individuals will form the initial cluster in which the possibility of inclusion of new individuals is evaluated; therefore, adopting the criterion that the mean intra-cluster distance must be less than the mean inter-cluster distance.

The inclusion or exclusion of the $\mathrm{k}$ accession in the cluster is made considering the following: - if $\mathrm{d}_{\text {(group) } \mathrm{k}} / \mathrm{n} \leq \Theta$, the $\mathrm{k}$ accession is included in the cluster; - if $\mathrm{d}_{\text {(group) } k} / \mathrm{n}>\theta$, the $\mathrm{k}$ accession is not included in the cluster, where $\mathrm{n}$ is the number of accessions that constitute the original cluster.

In this case, the distance between the individual $\mathrm{k}$ and the cluster formed by the accessions ij is given by:

$$
D_{(j) k}=d_{k}+d_{k}
$$

Genes, a genetic statistical software, was used to conduct dissimilarity analyses and Tocher method clustering (Cruz, 2006). 


\section{RESULTS AND DISCUSSION}

The information obtained via the dissimilarity matrix of sugarcane accessions, with the use of multicategorical variables utilized to generate Tocher method clustering data, resulted in the formation of eleven distinct clusters (Table 2). Cluster I, containing 18 treatments, was the largest set formed, including seventeen accessions and the cultivar SP80-1842 (SP71-1088 x H57- 5028), and it corresponded to $46.2 \%$ of the total treatments evaluated (Table 2 ).

\begin{tabular}{|c|c|c|c|c|c|c|c|c|c|c|c|}
\hline \multirow{2}{*}{$\frac{\text { Clusters }}{1}$} & \multicolumn{10}{|c|}{ Accessions/Varieties } & \multirow{2}{*}{$\frac{\%}{46.2}$} \\
\hline & $\mathrm{P} 11$ & 132 & N23 & L1 & L12 & L30 & L21 & L29 & L20 & L19 & \\
\hline & RV24 & N22 & L33 & RV25 & C31 & P34 & L27 & V37 & & & \\
\hline II & $\mathrm{P} 4$ & N28 & RV26 & & & & & & & & 7.7 \\
\hline III & P16 & P18 & P13 & & & & & & & & 7.7 \\
\hline IV & P6 & L9 & P35 & & & & & & & & 7.7 \\
\hline v & L8 & V39 & L2 & V36 & & & & & & & 10.3 \\
\hline VI & P5 & L10 & & & & & & & & & 5.1 \\
\hline VII & $\mathrm{L} 7$ & P14 & & & & & & & & & 5.1 \\
\hline VIII & V38 & & & & & & & & & & 2.6 \\
\hline IX & L15 & & & & & & & & & & 2.6 \\
\hline$x$ & L3 & & & & & & & & & & 2.6 \\
\hline XI & P17 & & & & & & & & & & 2.6 \\
\hline
\end{tabular}

Silva et al. (2005), using multivariate techniques to evaluate genetic divergence in 129 sugarcane cultivars, conducted an experiment in the municipality of Paranavaí (Paraná, Brazil), and they observed the formation of seven clusters using the Tocher method. Furthermore, the first of these clusters consisted of 108 cultivars that represented $83.72 \%$ of the studied samples. These results corroborate the results of the present study in that a greater number of treatments constituted the first group.

Cluster $\mathrm{V}$, with four treatments, was the second largest with $10.3 \%$ of the total cultivars examined in this study (Table 2), including two accessions and the cultivars RB867515 (RB72454 x unknown) and SP81-3250 (CP70-1547 x SP71-1279). Clusters II, III, and IV were composed of three accessions that contained $7.7 \%$ of those studied. Clusters $\mathrm{VI}$ and $\mathrm{VII}$ had two accessions per cluster, representing $5.1 \%$ of the total analyzed for each cluster.

Cluster VIII, IX, X, and XI contained only a single accession. Of these, cluster VIII, composed of the cultivar SP79-1011 (NA5679 x Co775), stood out. The results show the genetic divergence between the accessions and sugarcane varieties used in the region of Lavras, Minas Gerais, Brazil, and they corroborate reports presented in the literature.

Elias et al. (2007) studied genetic variability in traditional black common bean germplasm, and concluded that the Tocher optimization method maintains homogeneity within clusters and heterogeneity between the clusters. Thus, a greater number of individuals in a determined cluster is indicative of greater genetic similarity, and individuals that fit within the last cluster exhibit greater divergence relative to those in the first cluster. Genetic divergence among the treatments may be observed in the minimum and maximum dissimilarities detected in the results. The pairing between treatments P11 and I32, which were allocated to cluster I, denoted a dissimilarity of 0.39 (39.0\%) between them, and this was the minimum among all those studied. The other extreme lay in the 
pairing of treatments $\mathrm{P} 17$ and $\mathrm{L} 29$, with a dissimilarity of 0.85 , indicating divergence in $85.0 \%$ of the characteristics evaluated in these accessions.

Regarding the morphological characteristics obtained via the descriptors that led to the formation of the divergent groups, treatment P17 (cluster XI) stood out. P17 diverged from most of the treatments based on the characteristics studied, including the following: growth habit of the clump (classified in this case as "prostrate" on a scale of upright, lightly prostrate, and prostrate); dehusking (classified as "difficult" on a scale of natural, easy, medium, and difficult); and splitting (classified as "deep" on a scale of absent, shallow, medium, and deep). These characteristics indicated that this accession has traits that limit sugarcane production directed toward regional craft stills. Harvests are performed manually, without prior burning. Therefore, it is fundamental that the accessions exhibit natural or easy dehusking and upright growth habit. The occurrence of splitting reduces the quality and yield, and it is also a point of entry for insects and pathogens.

Relative to the other clusters, cluster $X$ (accession L3) exhibited the characteristics of a "short" distance between nodes and the presence of hairiness (classified as "a lot" on a scale of absent, little, medium, or a lot). It may also be inferred that this accession has characteristics that do not match regional demands for cachaça. Furthermore, clusters VIII (SP79-1011), VII (accessions L7 and P14), and IV (accessions P6, L9, and P35) have dehusking classified as "difficult", which is a non-desirable characteristic for craft still production because it hinders the cleaning of sugarcane at harvest and before milling.

It is fitting to mention that the existence of genetic variability among the studied accessions was evident, even though a large number of accessions were present in cluster I (Table 2).

It should also be emphasized that for the choice of varieties or accessions to be used in the production of craft-distilled cachaça, several important morphological traits (e.g., dehusking, the presence of hairiness, tillering, the presence of splitting, and growth habit) must be considered in addition to agronomic potential.

\section{CONCLUSIONS}

There was genetic divergence among the accessions and varieties studied. Accessions P17 and L29 were the most divergent, with a dissimilarity of 0.85 .

\section{Conflicts of interest}

The authors declare no conflict of interest.

\section{ACKNOWLEDGMENTS}

We would like to thank João Mendes Agroindústria e Comércio de Cachaça, a cachaça producer.

\section{REFERENCES}

Cruz CD (2006). Programa Genes: biometria. Editora UFV, Viçosa.

Cruz CD and Carneiro PCS (2006). Modelos biométricos aplicados ao melhoramento genético. 2 ed. Editora UFV, Viçosa.

Dantas AAA, Carvalho LG and Ferreira E (2007). Classificação e tendências climáticas em Lavras, MG. Cienc. Agrotec. 31: 1862-1866. 
Elias HT, Vidgal MCG, Gonela A and Vogt GA (2007). Variabilidade genética em germoplasma tradicional de feijão preto em Santa Catarina. Pesq. Agropec. Bras. 42: 1443-1449.

Franco MC, Cassini STA, Oliveira VR and Tsai SM (2001). Caracterização da diversidade genética em feijão por meio de marcadores RAPD. Pesq. Agropec. Bras. 36: 381-385.

Karasawa M, Rodrigues R, Sudré CP, Silva MP, et al. (2005). Aplicação de métodos de agrupamento na quantificação da divergência genética entre acessos de tomateiro. Hortic. Bras. 23: 1000-1005.

Marchioro VS, Carvalho FIF, Oliveira AC, Cruz PJ, et al. (2003). Dissimilaridade genética entre genótipos de aveia. Cienc. Agrotec. 27: 285-294.

Oliveira ACB, Sediyama MAN, Pedrosa MW, Garcia NCP, et al. (2004). Divergência genética e descarte de variáveis em alface cultivada sob sistema hidropônico. Acta Sci. Agron. 26: 211-217.

Rodrigues LS, Antunes IF, Teixeira MG and Silva JB (2002). Divergência genética entre variedades locais e cultivares melhoradas de feijão. Pesq. Agropec. Bras. 37: 1275-1284.

Silva CM, Gonçalves-vidigal MC, Vidigal filho PS, Scapim CA, et al. (2005). Genetic diversity among sugarcane clones (Saccharum spp.). Acta Sci. Agron. 27: 315-319.

Souza FF, Queiróz MA and Dias RSC (2005). Divergência genética em linhagens de melancia. Hortic. Bras. 23: 179-183. 